\title{
International Economics
}




\title{
INTERNATIONAL ECONOMICS
}

\section{Bo Södersten}

and

\section{Geoffrey Reed}

\author{
Third Edition
}


Bo Södersten 1970, 1980; Bo Södersten and Geoffey Reed 1994

All rights reserved. No reproduction, copy or transmission of this publication may be made without written permission.

No paragraph of this publication may be reproduced, copied or transmitted save with written permission or in accordance with the provisions of the Copyright, Designs and Patents Act 1988, or under the terms of any licence permitting limited copying issued by the Copyright Licensing Agency, 90 Tottenham Court Road, London W1P 9HE.

Any person who does any unauthorised act in relation to this publication may be liable to criminal prosecution and civil claims for damages.

First published in the USA 1970

First published in the UK 1971

Reprinted eight times

Second edition 1980

Reprinted eleven times

Third edition 1994

Published by

MACMILLAN PRESS LTD

Houndmills, Basingstoke, Hampshire RG21 6XS

and London

Companies and representatives

throughout the world

International edition 978-0-333-76365-0

\section{ISBN 978-0-333-76365-0}

DOI 10.1007/978-1-349-15030-4

ISBN 978-1-349-15030-4 (eBook)

A catalogue record for this book is available from the British Library.

This book is printed on paper suitable for recycling and made from fully managed and sustained forest sources.

$\begin{array}{rrrrrrrrrr}10 & 9 & 8 & 7 & 6 & 5 & 4 & 3 & 2 & 1 \\ 08 & 07 & 06 & 05 & 04 & 03 & 02 & 01 & 00 & 99\end{array}$

Copy-edited and typeset by Povey-Edmondson Okehampton and Rochdale, England

To Anna, Henrik, Erika and Viktor

To Sandra 


\section{Acknowledgements}

The authors and publishers are grateful to the following for permission to use copyright material:

Blackwell Publishers, Oxford, for tables from I. Trela and J. Whalley (1990) 'Global Effects of Developed Country Trade Restrictions on Textiles and Apparel', Economic Journal, 100, pp. 1190-205; from F. Brown and J. Whalley (1980) 'Equilibrium Evaluations of Tariff Cutting Proposals in the Tokyo Round and Comparisons with More Extensive Liberalisations of World Trade', Economic Journal, 90, pp. 836-66; and from C. T. Ennew, D. Greenaway and G.V. Reed (1990) 'Further Evidence on Effective Tariffs and Effective Protection', Oxford Bulletin of Economics and Statistics, 52, pp. 69-78.

GATT (General Agreement on Tariffs and Trade) for a table from GATT (1979) The Tokyo Round of Multilateral Trade Negotiations (Geneva).

Harvester-Wheatsheaf and New York University Press for a table from V. N. Balasubramanyam and D. R. Basu (1990) 'India: Export Promotion Policies and Export Performance' in C. R. Milner (ed.), Export Promotion Strategies.

International Monetary Fund for tables from K. Pilbeam (1992) International Finance (London: Macmillan), originally published in the IMF's Balance of Payments Yearbook (1990); and from G. C. Hufbauer and J. Schott (1985) Trading for Growth: The Next Round of Trade Negotiations (Washington, DC: Institute for International Economics), originally published in the IMF's International Financial Statistics: Yearbook.

Trade Policy Research Centre, University of Reading, for tables from D. Greenaway (1985) 'Clothing from Hong Kong and Other Developing Countries' in D. Greenaway and B. Hindley, What Britain Pays for Voluntary Export Restraints, Thames Essay No. 43 (London).

Oxford University Press for a table from W.M. Corden (1974), Trade Policy and Economic Welfare, and for a table from I. Little, T. Scitovsky and M. Scott (1970), Industry and Trade in Some Developing Countries: A Comparative Study. 
The United States Department of Commerce for a table from The Survey of Current Business.

The World Bank for a table based on Tables A8.3 and A8.4 in Finger, J. M. and Olechowski, A. (1987), The Uruguay Round: A Handbook for the Multilateral Trade Negotiations.

Helbing \& Lichtenhahn Verlag AG for a table from Greenaway, D. and Nam, C-H. (1988), 'Industrialisation and Macroeconomic Performance in Developing Countries under Alternative Liberalisation Scenarios', Kyklos, 41.

Professor A.O. Krueger and the National Bureau for Economic Research for a table based on Tables 6.2 and 6.3 in Krueger, A.O. (1978), Foreign Trade Regimes and Economic Development: Liberalization Attempts and Consequences.

Every effort has been made to contact all the copyright-holders, but if any have been inadvertently overlooked the publishers will be pleased to make the necessary arrangement at the first opportunity. 


\section{Contents}

List of Figures

$\mathrm{xxi}$

List of Tables

xxix

Preface to the Third Edition

xxxi

Introduction: International Economics and Economic Theory

xxxiii

\section{PART 1 THEORIES OF INTER- AND INTRA-INDUSTRY TRADE}

1 The Basic Geometry of Comparative Advantage and the Gains from Trade

1.1 Introduction 3

1.2 Absolute and comparative advantage 4

Adam Smith and the absolute advantage of trade 4

David Ricardo and the theory of comparative advantage 5

Ricardo on the gains from trade 6

1.3 Production, consumption and trade 9

The production-possibility curve 9

Community indifference curves $\quad 13$

1.4 The gains from trade 15

The gains from trade restated 15

$\begin{array}{ll}\text { The flaw in Ricardo's argument } & 17\end{array}$

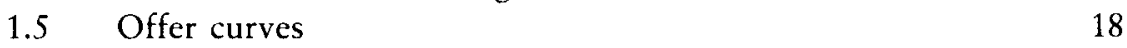

2 The Classical Model and the Specific Factors Model 23

2.1 Introduction 23

2.2 The classical model 23

Production possibilities in the classical model 23

Real wages under autarky $\quad 25$

Free trade with complete specialisation in both countries 25

The effect of the move to free trade on real wages $\quad 28$

Free trade with incomplete specialisation in the large country $\quad 29$

2.3 The specific factors model 30

Production possibilities in the specific factors model 30

Two countries differing in their endowments of capital 32 
Free trade and factor prices $\quad 34$

Two countries differing in their endowments of labour 36

Free trade and factor prices $\quad 38$

3 The Heckscher-Ohlin model 41

3.1 Introduction 41

3.2 Factors of production and the production-possibility curve 42

Linearly homogeneous production functions 42

Competitive factor markets: factor prices and factor intensities 44

Factor reversals $\quad 49$

The box diagram $\quad 51$

The production-possibility curve derived from the box diagram 55

Factor endowments and the range of factor prices $\quad 57$

3.3 Comparative advantage in the Heckscher-Ohlin model 59

3.4 Rewards to factors of production 65

Free trade and factor prices in the Heckscher-Ohlin model 65

Factor price equalisation in the Heckscher-Ohlin model 66

3.5 Adjustment over time in the Heckscher-Ohlin framework 69

4 Technology-Difference Models $\quad 72$

4.1 Introduction 72

4.2 Technology differences in the specific factors model 73

4.3 Technology differences in the Heckscher-Ohlin Model 76

4.4 Adjustment to changes in technology 80

4.5 Imitation-gap theories of trade 82

4.6 Product-cycle theories of trade 85

$\begin{array}{lll}4.7 & \text { Increasing returns to scale } & 87\end{array}$

5 The Gains from Inter-Industry Trade, the Distribution of Income, and Adjustment $\quad 89$

$\begin{array}{lll}5.1 & \text { Introduction } & 89\end{array}$

5.2 Gains from inter-industry trade 89

The construction of non-intersecting community indifference curves $\quad 90$

Ordering the indifference curves using a social welfare function 93

Changes in the distribution of income 95

5.3 A more general approach to the gains from trade 95

$\begin{array}{lll}5.4 & \text { The adjustment problem } & 98\end{array}$ 
6 Empirical Testing of Inter-Industry Trade 103

6.1 Introduction 103

6.2 The Leontief Paradox 104

Leontief's test of the Heckscher-Ohlin theorem 104

Criticisms of the data and the methodology 105

The unbalanced trade problem 105

Human capital explanations 106

$\begin{array}{ll}\text { Natural resource explanations } & 107\end{array}$

Demand reversals 108

Factor-intensity reversals 109

6.3 Testing models based on technology differences 111

Labour productivity and comparative advantage $\quad 111$

6.4 Technological-gap and product-cycle models 113

6.5 Econometric studies 113

$\begin{array}{lll}6.6 & \text { Summary and conclusions } & 114\end{array}$

7 Factor Accumulation and Technological Progress in $\begin{array}{ll}\text { Inter-Industry Trade } & 117\end{array}$

$\begin{array}{lll}7.1 & \text { Introduction } & 117\end{array}$

7.2 The effects of growth on trade 118

$\begin{array}{lll}7.3 & \text { Immiserising growth in a large country } & 122\end{array}$

7.4 Increases in the endowments of factors of production 124 The Rybczynski Theorem 125

Balanced growth in labour and capital 127

7.5 Technical progress and international trade 129

The classification of technical progress 129

Neutral technical progress and the terms of trade 132

Capital-saving technical progress in the capital-intensive industry 136

Labour-saving technical progress in the capital-intensive industry 139

7.6 Concluding comments on growth and trade 142

8 Intra-Industry Trade 146

8.1 Introduction 146

8.2 Intra-industry trade when there are many firms 147

The neo-Heckscher-Ohlin model 147

Neo-Chamberlinian models $\quad 149$

Neo-Hotelling models $\quad 152$

8.3 Oligopolistic models 162

The Brander-Krugman model 162

$\begin{array}{ll}\text { The reciprocal dumping model } & 165\end{array}$ 
Extensions and modifications of the Brander-Krugman model

Vertical differentiation and natural oligopolies

8.4 Conclusions

9 Empirical Work in Intra-Industry Trade 173

9.1 Introduction 173

Defining an industry 173

$\begin{array}{ll}\text { The level of aggregation } & 173\end{array}$

Measuring intra-industry trade $\quad 174$

The categorical aggregation problem 176

9.2 Some estimates of the extent of intra-industry trade 177

9.3 Explaining the level and growth of intra-industry trade $\quad 179$

9.4 Conclusions 184

\section{PART 2 INTERNATIONAL TRADE POLICY}

10 The Partial Equilibrium Analysis of Trade Policy 189

10.1 Protectionism 189

10.2 The partial equilibrium model of trade 190

Free trade between two large countries 191

Tariffs and the large country 193

The optimum tariff 196

10.3 Excess demand and supply analysis 197

10.4 Other distortions to free trade 199

An import tariff in a small country 200

An import subsidy in a small country 202

An export subsidy in a small country 203

An export tax in a small country 203

Import quotas 204

Voluntary export restraints 206

10.5 Tariffs in comparison with quantitative restrictions 207

10.6 Trade policy versus non-trade policy 209

11 The General Equilibrium Analysis of Trade Policy 213

11.1 Introduction 213

11.2 Small and large countries 213

The effects on a small country of imposing an import tariff $\quad 213$

The effects on a large country of imposing an import tariff 215

$\begin{array}{lll}11.3 & \text { Offer curves and the optimum tariff } 218\end{array}$

Trade indifference curves 218

Deriving the free-trade offer curve 222

The tariff-ridden offer curve 223 
Tariff-ridden equilibrium 225

The optimum tariff for a large country 227

11.4 Tariffs and real rewards to factors of production 231

When no factors are mobile 231

When only labour is mobile 232

When both factors are mobile: the Stolper-Samuleson theorem 233

11.5 Tariffs and real rewards to factors of production over time 235

11.6 The Metzler Paradox 235

11.7 The Lerner Symmetry Theorem 238

12 Trade Policy and Distortions in Domestic Markets 240

12.1 Introduction 240

12.2 Specified production and consumption targets 241

12.3 Domestic distortions in commodity markets 243

A single domestic producer in a small country 243

A single domestic producer in a large country 246

A negative production externality 247

12.4 Domestic distortions in factor markets 250

12.5 The hierarchy of policies 255

12.6 The infant-industry argument for protection 256

12.7 Trade policy for development: some initial comments 261

13 Trade Policy and Imperfect Competition 263

13.1 Introduction 263

13.2 Trade policy with monopolistic competition 264

The Falvey neo-Heckscher-Ohlin model 264

The Krugman neo-Chamberlin model 266

The Lancaster neo-Hotelling model 266

13.3 Tariffs and monopolies 268

Protecting a domestic single producer with increasing costs $\quad 268$

Tariffs as a stimulant to exports 269

'Snatching' rent from a foreign monopoly 271

13.4 Tariffs, subsidies and duopoly 272

Strategic trade policy in a duopoly setting $\quad 272$

Retaliation 276

Entry deterrence and entry promotion $\quad 276$

$\begin{array}{ll}\text { Tariffs and export promotion } & 277\end{array}$

13.5 Concluding remarks 277

14 Further Topics in Trade Theory and Policy 279

14.1 Introduction 279

14.2 Non-traded goods 279

'Dutch disease' 283 
14.3 Trade in intermediate goods 284 Intermediate and final goods 284

Gross production, net production, and value-added $\quad 285$ The pattern of trade 286

Intermediate goods and the production-possibility curve $\quad 288$

14.4 Effective tariffs, effective protection and domestic resource cost analysis 291

Effective tariffs and effective protection 291

Empirical estimates of effective tariffs and protection 293

Domestic resource cost analysis 294

14.5 Trade in services 295

The distinction between goods and services 295

Defining and measuring international trade in services 296

Comparative advantage and international trade in services 296

Foreign direct investment and international trade in services 297

National policies and services 298

14.6 Price stabilisation 298

Stabilising domestic prices by using variable trade taxes
and subsidies

15 The Political Economy of Protection 303

15.1 Introduction 303

15.2 Political markets 304

The median voter model $\quad 305$

Lobbying $\quad 307$

The optimal amount of lobbying $\quad 308$

15.3 The choice of protective instrument 309

15.4 Tariff lobbying by a single domestic producer 312

15.5 'Capturing' anti-dumping legislation 313

15.6 Rent-seeking 315

15.7 Empirical work on the political economy of protection 317

16 The Theory of Customs Unions 322

$\begin{array}{lll}16.1 & \text { Introduction } & 322\end{array}$

16.2 Trade creation and trade diversion 323

16.3 A customs union compared with a non-preferential trade policy

16.4 The export interest 329

Customs unions and the export interest 329

The export interest and third country tariffs 331 
16.5 Setting the common external tariff to avoid trade diversion 333

16.6 Customs unions when there are economies of scale 335 Made-to-measure tariffs $\quad 340$

16.7 Intra-industry trade and customs union formation 341

16.8 When will a customs union increase welfare? 342

16.9 Customs unions and the terms of trade 343

16.10 Dynamic considerations 344

16.11 Other barriers to trade 344

16.12 Higher levels of economic integration 345

16.13 Empirical findings $\quad 346$

$\begin{array}{ll}16.14 & \text { Summary and conclusions }\end{array} 347$

17 The General Agreement on Tariffs and Trade 349

17.1 Introduction 349

17.2 The origins, objectives and structure of the GATT 350

The International Trade Organisation and the GATT $\quad 350$

The objectives of the GATT 351

The structure of the GATT 352

17.3 The Principles of the GATT 352

Non-discrimination $\quad 352$

Reciprocity $\quad 353$

Transparency $\quad 354$

The GATT and neo-mercantilism 354

The MFN clause and discrimination against countries $\quad 355$

17.4 Exceptions to the GATT 356

Balance-of-payments problems $\quad 356$

Regional groupings $\quad 357$

Tariff preferences $\quad 357$

Dumping 358

The Multi-Fibre Arrangement 358

Agriculture $\quad 359$

Services $\quad 359$

17.5 The GATT Rounds between 1947 and 1961

17.6 The Kennedy Round (1964-67) 361

17.7 The Tokyo Round (1973-79) 363

17.8 The Uruguay Round (1986- ) 364

United States Policy in the 1980s 365

Punta del Este and the Uruguay Round Agenda 367

The Montreal Impasse and the Geneva Accord 368

The Draft Final Act and the Washington Accord 369

$\begin{array}{ll}\text { Other issues } & 370\end{array}$

17.9 Unsettled issues and future problems 371 
18 Trade Policy and the Less-Developed Countries 374

$\begin{array}{lll}18.1 & \text { Introduction } & 374\end{array}$

18.2 UNCTAD and the world trading system 375

18.3 The Generalised System of Tariff Preferences 376

18.4 The support and stabilisation of international commodity $\begin{array}{ll}\text { prices } & 383\end{array}$

18.5 Supporting prices in the long run 385

$\begin{array}{ll}\text { 18.6 Stabilising prices in the medium and short run } & 388\end{array}$

$\begin{array}{lll}18.7 & \text { International buffer stocks } & 393\end{array}$

18.8 International quota agreements and multilateral contract $\begin{array}{ll}\text { systems } & 395\end{array}$

18.9 Recent experience with international commodity agreements

18.10 The United Nations Integrated Programme for Commodities

$\begin{array}{ll}18.11 & \text { Compensatory finance schemes } \\ 18.12 & 398\end{array}$

$\begin{array}{ll}18.12 \text { Concluding remarks } & 400\end{array}$

19 Import-Substitution versus Export-Promotion 404

$\begin{array}{lll}19.1 & \text { Introduction } & 404\end{array}$

19.2 Export pessimism 405

19.3 Defining import-substitution and export-promotion 408

$\begin{array}{lll}19.4 & \text { Import-substitution } & 409\end{array}$

The background to the import-substitution strategy 409

The anatomy of controls on foreign trade $\quad 410$

Income distribution and savings $\quad 416$

$\begin{array}{ll}\text { Discrimination against agriculture } & 418\end{array}$

Choice of technology and effects on employment 419

19.5 Import substitution versus export promotion 422

Structural adjustment loans and 'conditionality' $\quad 425$

Empirical evidence $\quad 426$

19.6 Concluding remarks on development strategies 431

20 Empirical Studies of Trade Policy 437

20.1 Introduction 437

20.2 Estimating the costs of tariff protection using the partial $\begin{array}{ll}\text { equilibrium approach } & 438\end{array}$ The small-country case $\quad 438$

The large-country case $\quad 440$

20.3 Estimating the costs of a quantitative restriction on
imports using the partial equilibrium approach 
20.4 Computable general equilibrium analyses 443

Specifying the model and the functional forms 443

The 'benchmark' data set 446

Calibration of the model and replication of the benchmark data

Using the CGE model to investigate the effects of policy changes

Some of the pros and cons of CGE modelling 448

20.5 Some analyses of the costs of protection 448

Sectoral protection - the Multi-Fibre Arrangement 449

Multilateral liberalisation - the Tokyo Round $\quad 452$

20.6 Comments and conclusions 453

21 International Factor Movements 456

21.1 Introduction 456

21.2 International factor movements in a Heckscher-Ohlin

21.3 The migration of labour 458

Positive effects $\quad 458$

Welfare effects $\quad 460$

Some policy implications of migration 461

21.4 Foreign portfolio investment 462

Positive and welfare effects of portfolio investment 463

Policy implications: the transfer problem $\quad 464$

21.5 Summary and conclusions 465

22 Direct Investments and the Multinational Enterprise 467

$22.1 \quad$ Introduction $\quad 467$

22.2 Direct investments and multinational enterprises 469

The theory of direct investments $\quad 470$

The product cycle hypothesis $\quad 471$

Market imperfections and FDI 471

'Management' as a factor of production 473

22.3 Barriers to trade and FDI $\quad 474$

22.4 Dunning's 'eclectic theory' 475

22.5 Some other considerations 476

22.6 Empirical studies of FDI 477

22.7 Taxation and the transfer pricing problem 478

22.8 FDI and the balance of payments 482

22.9 Some other effects 483

In the source country 483

In the host country $\quad 484$ 
Control 485

External benefits of FDI to the host country 486

Direct investments and exploitation $\quad 487$

22.10 Policy responses in host countries 488

'Unbundling the package' 489

Export-processing zones $\quad 490$

Trade-related investment measures 491

22.11 Summary and conclusions 492

\section{PART 3 INTERNATIONAL MACROECONOMICS}

23 The Balance of Payments 497

23.1 Introduction 497

23.2 The balance of payments: book-keeping 498

The current account 499

The capital account $\quad 500$

The remaining items in the balance of payments 502

23.3 Balance of payments: surpluses and deficits 504

Autonomous and accommodating items $\quad 505$

Deficir and surplus in the current account 506

The basic balance $\quad 507$

The official settlements concept $\quad 507$

23.4 The external wealth account 508

23.5 Summary and conclusions 508

24 The Market for Foreign Exchange 509

24.1 Introduction 509

24.2 Institutional aspects of foreign-exchange markets 510

Defining the foreign exchange rate 510

The structure of the foreign-exchange market 511

The demand for foreign exchange $\quad 512$

The supply of foreign exchange 517

24.3 A simple model of a spot exchange market 512

24.4 Stability in a floating exchange-rate market 522

24.5 Government intervention in the foreign-exchange market: fixing the exchange rate 524

24.6 An example of adjustment in the foreign-exchange market 525

24.7 The forward-exchange market 527

Interest rate arbitrage and 'covered interest parity' $\quad 528$

Hedging $\quad 530$

Speculation $\quad 531$

24.8 Comments and conclusions 531 
25 Foreign Trade and National Income 533

25.1 The import function 533

25.2 The determination of national income in a small open economy

The condition for national income equilibrium in a small open economy 535

National income multipliers in a small open economy 537

Introducing government expenditure and taxation $\quad 540$

25.3 The determination of national income in a large open economy 543

25.4 The international transmission of disturbances 547

Transmission under fixed exchange rates: some empirical evidence

Transmission under floating exchange rates 548

25.5 An initial look at internal and external balance $\quad 550$

26 The Capital Account $\quad 554$

26.1 Introduction 554

26.2 A flow theory of capital movements 555

26.3 A stock theory of the capital account 556

A stock model with fixed exchange rates 561

A stock model with floating exchange rates 561

Stock models versus flow models $\quad 563$

26.4 The monetary approach 563

26.5 Summary and conclusions 569

27 The Determination of a Floating Exchange Rate 571

27.1 Introduction 571

27.2 A fixed price model with perfectly immobile capital 571

27.3 A fixed price model with capital mobility 573

The IS schedule for a small open economy $\quad 574$

The $L M$ schedule for a small open economy $\quad 574$

The BP schedule for a small open economy 574

Equilibrium in the Mundell-Fleming model with floating exchange rates $\quad 578$

Monetary and fiscal expansion in the Mundell-Fleming model

27.4 Purchasing Power Parity 581

Absolute and relative PPP $\quad 582$

Criticisms of PPP $\quad 582$

Empirical tests of the PPP hypotheses 583

27.5 A flexible price monetary model $\quad 584$ 
27.6 The Dornbusch 'sticky price' model 587

Equilibrium in the money market $\quad 588$

Equilibrium in the goods market $\quad 590$

Long-run equilibrium 591

Monetary expansion and exchange-rate overshooting $\quad 592$

27.7 Empirical evidence on monetary models 594

27.8 Summary and conclusions $\quad 595$

28 Macroeconomic Policy with Floating Exchange Rates 597

28.1 Introduction $\quad 597$

28.2 The policy environment and policy targets 598

The environment $\quad 598$

Policy targets $\quad 598$

28.3 The Mundell-Fleming model 599

Monetary policy and capital mobility $\quad 599$

Fiscal policy and capital mobility 601

Combining monetary and fiscal policy when there are two policy targers 604

28.4 The monetary approach 606

An expansion in the money supply under floating exchange rates 608

An increase in aggregate supply under floating exchange rates 608

28.5 Summary and conclusions 611

29 Macroeconomic Policy with Fixed and Pegged Exchange Rates

29.1 Introduction 613

$\begin{array}{ll}29.2 & \text { The gold standard } \\ 29.3 & 615\end{array}$

29.3 Devaluation: the elasticities approach 617

29.4 Devaluation: the absorption approach 620

The effects of devaluation on national income 621

The effects of devaluation on direct absorption $\quad 622$

Devaluation and non-traded goods 623

29.5 Internal and external balance 624

Combining exchange-rate adjustments and fiscal policy $\quad 624$

The 'piecemeal' approach and the assignment problem $\quad 627$

Combining monetary and fiscal policy 628

29.6 Pegged exchange rates with capital mobility 630

The Mundell-Fleming model $\quad 630$

Monetary policy and sterilisation 631

29.7 Pegged exchange rates and the monetary approach 635

Devaluation under the monetary approach 635 
An expansion in the money supply under the monetary approach

An increase in income under the monetary approach

29.8 Summary and conclusions

30 Two Debates: Exchange-Rate Systems and Policy

Co-ordination

30.1 Introduction

30.2 Fixed versus floaring exchange rates: the traditional approach

Exchange-rate uncertainty, trade and investment

The effects of speculation

Exchange-rate regimes and macroeconomic policy

646

30.3 Fixed versus floating exchange rates: modern approaches

Economic stability in the Mundell-Fleming model

Introducing a government objective function

Optimising macromodels

30.4 International co-ordination of macroeconomic policy

The gains from policy co-ordination

652

Some problems associated with policy co-operation

655

'Rules' versus 'one-off' negotiations

656

30.5 Conclusions

31 The International Monetary System

31.1 Introduction

31.2 Some basic concepts

The consistency problem

Political will, hegemony and seigniorage 661

31.3 The Bretton Woods system 662

The background 662

The creation of the International Monetary Fund 663

The IMF in the 1950s and 1960s 664

International liquidity: the 'Triffin Dilemma' 666

The introduction of Special Drawing Rights 667

The breakdown of the Bretton Woods system: 1967-73 668

The Smithsonian Agreement $\quad 668$

The international monetary system since the demise of

Bretton Woods

31.4 The Eurocurrency markets $\quad 671$

31.5 The European Monetary System 672

The record and prospects of the EMS $\quad 674$

$\begin{array}{ll}31.6 & \text { The international debt crisis } \\ 31.7 & 675\end{array}$

$\begin{array}{lll}31.7 & \text { Summary and conclusions } & 677\end{array}$ 
$\mathrm{xx}$ Contents

$\begin{array}{ll}\text { Further Reading } & 681\end{array}$

Bibliography $\quad 682$

Author Index $\quad 699$

$\begin{array}{ll}\text { Subject Index } & 702\end{array}$ 


\section{List of Figures}

1.1 A concave production-possibility curve 10

1.2 Long- and short-run production-possibility curves 11

$\begin{array}{lll}1.3 & \text { The role of shifting prices } & 12\end{array}$

1.4 Community indifference curves 13

1.5 Community indifference curves assuming optimal income redistribution

$\begin{array}{lll}1.6 & \text { Equilibrium under autarky } & 16\end{array}$

1.7 Equilibrium under free trade 17

$\begin{array}{lll}1.8 & \text { Equilibria under international trade } & 19\end{array}$

1.9 Offer curve for the cloth exporting country 20

1.10 Free trade equilibrium shown with offer curves 21

1.11 Free trade equilibrium for a small country 22

2.1 Deriving the classical production-possibility curve 24

2.2 Different technology results in different production-possibility curves $\quad 26$

2.3 Free trade with both countries specialising completely 27

2.4 Free trade with incomplete specialisation in the large country 29

2.5 Deriving the production-possibility curve in the specific factors model

2.6 Different capital endowments give different production-possibility curves 33

2.7 Country $A$ will have the comparative advantage in good $Y \quad 34$

2.8 Different production-possibility curves when countries have different labour endowments

2.9 A possible free trade equilibrium 38

3.1 Isoquants with constant returns to scale 43

3.2 Equilibrium in production under free competition 45

3.3 Factor prices, factor intensities and production costs 46

3.4 Factor prices, factor intensities and relative costs 48

3.5 Isoquants cut twice 49

3.6 Factor intensity reversals $\quad 50$

3.7 Factor prices and relative costs with a factor reversal 51

3.8 Factor allocation in the box diagram 52

3.9 Outputs, factor price ratios and capital-labour ratios in the box diagram 
3.10 The box diagram and the production-possibility curve 56

3.11 Factor endowments and the range of factor prices 58

3.12 The physically capital-rich country may also be the country where capital is relatively cheap

3.13 The physically capital-rich country may be the country where capital is relatively expensive

3.14 Differences in factor endowments

3.15 The physically capital-rich country is biased towards producing the capital-intensive good

3.16 Demand factors offsetting production bias 64

3.17 Equalisation of relative factor prices with incomplete specialisation

3.18 Factor price equalisation with incomplete specialisation

3.19 Relative factor prices are not equalised with complete specialisation

3.20 Gains from trade in the short, medium and long run $\quad 70$

4.1 A difference in technology in the $Y$ industry 73

4.2 A scale difference in technology in the capital-intensive industry

4.3 The production boxes for the two countries 78

4.4 Production-possibility curves in the medium and long term $\quad 78$

4.5 Free trade and factor prices 80

4.6 Adjustment following an improvement in technology in the import-competing good

4.7 The imitation-gap model 84

4.8 Trade and increasing returns to scale $\quad 87$

5.1 Identical and homothetic tastes and community indifference curves

5.2 Greater quantities of both goods give a set of 'higher' community indifference curves

5.3 Maintaining the same proportionate shares in national income

5.4 Consumption possibilities for a small country under autarky and free trade

$\begin{array}{lll}\text { 5.5 } & \text { Utility-possibility frontiers for a small country } & 97 \\ \text { 5.6 } & \text { Gains from trade in the short, medium and long run } & 99\end{array}$

5.7 Factor allocation in the short, medium and long run 101

6.1 The physically capital-rich country may export its labour-intensive good when there is a factor reversal $\quad 110$

7.1 Neutral growth in production and consumption

7.2 Neutral growth in trade without neutral growth in production and consumption

7.3 An example of anti-trade biased growth 
$\begin{array}{lll}7.4 & \text { Bias in the growth of production } & 121\end{array}$

7.5 Bias in the growth of consumption 123

7.6 Immiserising growth for a large country 124

7.7 The Rybczynski Theorem: growth in the endowment of labour

7.8 The effect of growth in the endowment of labour on the production-possibility curve 127

7.9 Balanced growth in the endowments of labour and capital 128

7.10 The effects of neutral innovation on the production function

7.11 Labour-saving technical progress 131

7.12 Capital-saving technical progress 132

7.13 Neutral technical progress in the capital-intensive sector and factor allocation

7.14 Real returns to factors of production after neutral technical progress in the capital-intensive sector

7.15 Neutral technical progress in the capital-intensive sector and the production-possibility curve

7.16 Capital-saving technical progress in the capital-intensive sector and factor allocation

7.17 Real returns to factors of production after capital-saving technical progress in the capital-intensive sector

7.18 Capital-saving technical progress in the capital-intensive sector and the production-possibility curve

7.19 Labour-saving technical progress in the capital-intensive sector

7.20 Real returns to factors of production after labour-saving technical progress in the capital-intensive sector

7.21 Labour-saving technical progress in the capital-intensive sector and the production-possibility curve

8.1 The spectrum of varieties

8.2 A consumer's demand falls as the distance between a variety and his ideal variety increases

8.3 Autarkic and free trade equilibria for a typical firm 157

8.4 Consumers' surplus under autarky 158

8.5 Changes in consumers' surplus with free trade 15y

8.6 Changes in producers' surplus with free trade 160

8.7 Equilibrium in the home market 165

8.8 Equilibrium in the home market with transport costs 167

$\begin{array}{ll}8.9 & \text { Duopoly equilibrium with a vertically differentiated good } 169\end{array}$

10.1 Autarkic equilibrium in $A$ and $B \quad 192$

10.2 Joint equilibrium in $A$ and $B$ under free trade 192

10.3 Joint equilibrium in $A$ and $B$ with a tariff 194 
10.4 The effects on welfare of increasing the tariff for a large country

10.5 Free trade equilibrium in $A$ and $B$

10.6 Tariff-ridden equilibrium in $A$ and $B$

10.7 The optimum tariff for a large importing country 199

10.8 A small importing country imposing a tariff 200

10.9 The level of welfare in a small country as its tariff is increased

10.10 A small importing country imposing a subsidy 202

10.11 A small exporting country imposing a subsidy 203

10.12 A small exporting country imposing an export tax 204

10.13 A small exporting country imposing an import quota 205

10.14 The effects of a fall in the world price under a tariff and a quota

10.15 The effects of an increase in domestic demand under a tariff and a quota

10.16 The effects of a tariff and of the equivalent production subsidy

11.1 A tariff will reduce the welfare of a small country 214

11.2 A tariff that reduces welfare in a large country 216

11.3 A tariff that increases welfare in a large country 217

11.4 Deriving the basic trade indifference curve 219

11.5 Deriving higher trade indifference curves 221

11.6 Deriving the free trade offer curve 223

11.7 Deriving a tariff-ridden offer curve 224

11.8 The effects of increases in the tariff on tariff-ridden offer curves

11.9 The effects of a tariff for a small country 226

11.10 The effects of a tariff for a large country 227

$\begin{array}{ll}11.11 \text { The optimum tariff for a large country } & 228\end{array}$

11.12 Retaliation by the second country 230

11.13 Policy equilibrium as the outcome of a tariff war 231

11.14 The Stolper-Samuelson Theorem 234

11.15 The Metzler Paradox 236

12.1 Obtaining a specified output of the import-competing good 241

12.2 Obtaining a specified consumption of the import-competing good

12.3 A single domestic producer in a small importing country 244

12.4 Apparent and true comparative advantage for a small country

12.5 A negative externality in agricultural production: a tariff may increase welfare

12.6 A negative externality: a tariff may decrease welfare 
12.7 A distortion in the labour market will lead to suboptimal production

12.8 The effect of a labour market distortion on the production-possibility curve

12.9 A distortion in the labour market: free trade may reduce welfare

12.10 Distortion in the labour market: the optimal policy 253

12.11 The infant-industry argument for protection 257

13.1 A single domestic producer with a tariff 269

13.2 A single domestic producer exporting with the aid of a tariff

13.3 Snatching rent from a foreign monopolist 271

13.4 A production subsidy in a simple duopoly model 274

13.5 A tariff in a simple duopoly model 275

14.1 Equilibrium in the production and consumption of traded and non-traded goods

14.2 The relative price of the non-traded good and the real wage 282

14.3 Trade with final and intermediate goods 287

14.4 Intermediate goods and the production-possibility curve 289

14.5 Consumption and production when the intermediate good is imported

14.6 Domestic price stabilisation by a small country 300

14.7 Domestic price stabilisation by a large country 301

15.1 The demand for and supply of tariff protection 308

15.2 Lobbying for a quantitative restriction compared with lobbying for a tariff

15.3 A single domestic producer lobbying for a tariff 312

16.1 A case with trade diversion and trade creation 326

16.2 The Cooper and Massell argument 328

16.3 Trade diversion may reduce welfare for both partners 330

16.4 The Wonnacotts' analysis 332

16.5 A CET that avoids trade diversion 334

16.6 Customs union formation when both countries have
decreasing cost industries initially

16.7 Customs union formation when only one country has a decreasing cost industry initially

16.8 Customs union formation when neither country has a decreasing cost industry initially

18.1 Tariff preferences applied to a specified import volume $\quad 378$

18.2 The operation of an export cartel 386

18.3 An export cartel when demand is contracting 387

18.4 Price stabilisation when supply is unstable 391

18.5 Using a buffer stock to stabilise prices 393 
20.1 A small importing country removing a tariff

20.2 Net gains and losses to both countries from the elimination of a tariff

20.3 A flowchart for constructing and running a CGE model

21.1 International factor mobility will put the world on its production-possibility frontier

21.2 The positive effects of labour migration 459

21.3 The welfare effects of labour migration 461

21.4 The effects of portfolio investment 463

24.1 Import demand and export supply for A's importables $\quad 512$

24.2 Deriving the $\$$ price for $A$ 's importables when $£ 1=\$ 2$

24.3 The effects of an appreciation of A's currency on its import volume

24.4 The importing country's demand schedule for the foreign currency

24.5 The supply of foreign exchange

24.6 A 'normally sloped' supply curve for the foreign currency 519

24.7 A 'backward sloping' supply curve for the foreign currency 520

24.8 Equilibrium in the foreign exchange market

24.9 Offsetting the effect of a decrease in demand for the foreign currency

24.10 Adjustment of the exchange rate to $A$ imposing a tariff

24.11 The effects of a tariff when there is an exchange-rate effect $\quad 527$

25.1 A linear import function

25.2 National income and the balance of trade

25.3 The effects of an increase in domestic investment on national income and the balance of trade

25.4 The effects of an increase in exports on national income and the balance of trade

25.5 Including the government in the small open economy model

25.6 The effects of reducing government expenditure 542

25.7 The effects of increasing the tax rate

25.8 Simultaneous national income equilibrium for two large countries

25.9 The effects on national incomes of an increase in autonomous expenditure for two large countries

25.10 The effect of an increase in investment when the exchange rate is floating

26.1 A flow model of international capital movements 556

26.2 Possible combinations of expected return and riskiness 557

26.3 Risk-averse preferences $\quad 558$

26.4 The optimum portfolio 559 
26.5 The aggregate demand and supply schedules in the monetary model

565

26.6 The purchasing power parity schedule 566

26.7 The money supply and the level of foreign exchange reserves

567

26.8 General equilibrium in the monetary approach 568

27.1 Joint determination of real income and the exchange rate 572

27.2 Deriving the $I S$ schedule for an open economy 574

27.3 Deriving the $L M$ schedule for an open economy 576

27.4 The BP schedule for a small open economy 577

27.5 Equilibrium in the Mundell-Fleming model 579

27.6 Monetary expansion in the Mundell-Fleming model 580

27.7 Fiscal expansion in the Mundell-Fleming model 581

27.8 Long-run equilibrium in the Dornbusch model 590

27.9 Unexpected monetary expansion in the Dornbusch model 593

28.1 Monetary policy in the Mundell-Fleming model with limited capital mobility

600

28.2 Fiscal policy in the Mundell-Fleming model with limited capital mobility - Case 1

602

28.3 Fiscal policy in the Mundell-Fleming model with limited capital mobility - Case 2

603

28.4 Using monetary and fiscal policy to attain two policy targets

605

28.5 Pursuing two targets with one instrument: 'stop-go' policy 606

28.6 General equilibrium in the monetary approach 607

28.7 An increase in money supply in the monetary approach 609

28.8 An increase in aggregate supply in the monetary approach 610

29.1 The 'J-curve effect' 619

29.2 The Salter-Swan diagram 625

29.3 Mixing policies to obtain the policy goal 626

29.4 The assignment problem with exchange rate and fiscal policies

29.5 Internal and external balance using monetary and fiscal policy

29.6 A surplus in the balance of payments in the

Mundell-Fleming model

29.7 Sterilised and unsterilised intervention in the foreignexchange market

29.8 Internal and external balance in the Mundell-Fleming model

29.9 Monetary and fiscal policy when there is perfect capital mobility

29.10 Devaluation under the monetary approach 
29.11 A money supply expansion under the monetary approach 638

29.12 An increase in income under the monetary approach 639

30.1 Deriving the reaction curve for country $A \quad 653$

30.2 The gains from policy co-ordination 654 


\section{List of Tables}

1.1 Cost comparisons

1.2 Opportunity costs

6

6.1 Capital and labour needed to reduce exports and increase import-substitutes by $\$ 1$ million in the United States in 1947

7.1 Technical progress in the capital-intensive sector and real rewards to factors of production

9.1 Calculating the Grubel and Lloyd index for hypothetical values of $X_{j}$ and $M_{j}$.

9.2 Calculating the Grubel and Lloyd Index for different levels of aggregation

9.3 Average levels of intra-industry trade in the United Kingdom in 1977 (Grubel-Lloyd Index)

9.4 Intra-industry trade at the three-digit level in the United Kingdom in selected years

9.5 Intra-industry trade in selected countries in $1980 \quad 179$

9.6 Average levels of intra-industry trade for country types in 1978

9.7 Evidence on the country-specific hypotheses 181

9.8 Evidence on the industry-specific hypotheses 182

9.9 Evidence on the policy-based hypotheses 184

12.1 A hierarchy of policies 255

14.1 UK nominal and effective tariffs by sector, 1986

15.1 Anti-dumping cases brought by and against selected countries between 1980 and 1986

16.1 Production cost of commodity $X$ in three countries 324

17.1 Tariff changes in the Tokyo Round 364

17.2 Negotiating groups in the Uruguay Round 368

19.1 Post-war annual percentage growth rates of world output and trade

19.2 Annual average percentage growth rates for India's exports and estimated effective exchange rate ratios

19.3 Imports as a percentage of GDP at current prices

19.4 Trade orientation and various economic indicators

19.5 Estimates of bias and of the ratio of effective exchange rates for five LDCs

20.1 The gains and losses for a small country removing a tariff 
20.2 Net gains and losses for the importing and exporting countries in the large-country case

20.3 Estimated changes in consumption, domestic production and imports following liberalisation of trade in textiles in the United Kingdom, 1982

20.4 Estimated costs of protection of clothing in the United Kingdom, 1982

20.5 Estimated welfare effects of liberalisation of the MFA for the United States, Canada, the EC and the developing countries

20.6 Welfare gains from the Tokyo Round tariff reductions and from complete liberalisation by the developed countries

22.1 An example of transfer pricing

22.2 Earnings on US direct investments abroad (percentage of book value at the beginning of year)

22.3 Balance-of-payments effects of a direct investment 482

23.1 Current account summaries for four countries, 1989

23.2 Capital account summaries for four countries, 1989

23.3 Balance-of-payments summaries for four countries, $1989 \quad 504$ 


\section{Preface to the Third Edition}

The first edition of International Economics, written by Bo Södersten, was published in Swedish in 1969, with the American and British editions following in 1970 and 1971. The second edition was published in 1980. This third edition has been extensively rewritten by Bo Södersten and Geoffrey Reed.

The first and second editions were well received, and used in many countries. Their aim was to present a reasonably rigorous treatment of international economics in a way that would be accessible both to undergraduate students and to others with a general interest in economics and international affairs. The emphasis was on theory, although problems of economic policy were discussed throughout. The intention was to provide the reader with theoretical tools that could be applied to various kinds of problems, not just those that happened to be topical when the book was published.

This intention has been maintained in the third edition. There have, however, been many new developments in both economic theory and the institutional setting since the second edition, and the new edition has been substantially revised to take account of these.

Part I is concerned with the pure theory of international trade. It starts with the classical and neo-classical models of inter-industry trade that have been the mainstay of trade theory since the early nineteenth century, and are still much in use today. Such theories are concerned with explaining the determinants of what was, for many years, the dominant pattern of trade, with each country exporting the output of some industries and importing the output of others. More recently it has become apparent that much trade, at least between developed countries, is intra-industry in nature: that is, countries simultaneously import and export the same type of good. A major feature of recent trade theory has been the development of models explaining this phenomenon, usually in terms of product differentiation and economies of scale, and a discussion of such theories is included in Part 1. The gains from international trade, and the adjustment problems faced when a country opens its market to foreign competition, are discussed in the context of both types of trade.

Part II deals with trade policy. The reduction since the Second World War in the 'old' forms of protection, notably tariffs and quotas, has been to some extent restraints, accompanied by the development of regional trading blocs that combine free trade among members while maintaining 
barriers to trade with other countries. Part II examines the arguments for and against both the old and the new protectionism, including an account of the contribution made by the renewed interest in the political economy of protection, and the role of the General Agreement on Tariffs and trade in securing and maintaining trade liberalisation. It deals also with the question of the best trade strategies to be followed by developing countries, and with the influences of foreign investment and multi-national enterprises.

Part III concentrates on international macroeconomics, discussing both international monetary problems and the implementation of macroeconomic policy in an open economy. There have been major changes in the institutional setting in the last two decades, and it is arguable that further changes are inevitable. Such changes have provided the stimulus for both new economic theories and the revival of some others.

There has been a significant increase in empirical studies in all areas of international economics in recent years. This reflects the development of new theories, and the wish to test them against both each other and the older theories, and is made possible by the availability of more comprehensive and reliable data and the development of econometric and other quantitative techniques. Discussions of empirical analyses form an important part of the third edition.

The structure and contents of the third edition are in many ways similar to those of the second edition, and so the acknowledgements made there still apply. There is, however, much new material, and we are grateful to Kevin Dowd, David Greenaway, Robert Hine and Mervyn Lewis for their willingness to read earlier efforts.

Bo SÖDERSTEN

Geoffrey Reed

Lund

Nottingham 


\section{Introduction: International Economics and Economic Theory}

Today the national state is the dominant political entity. Most countries, from an economic point of view, are still intimately linked with others. Two - the United States and China - could conceivably withdraw from the world economy without disastrous consequences to themselves. For other countries such an act would border on the unthinkable. It would bring about not only a drastic lowering of economic welfare but also a complete change of ways of life. For practical purposes, all countries must accept the fact that they are part of a world economy. No country can escape its role in the system of interdependent trading nations.

There now seems little doubt that the degree of interdependence among nations has increased markedly over the last two decades or more. World trade has grown exceptionally fast in the post-war years, both absolutely and relative to national incomes. The forces behind the internationalisation process have been strong. Technical progress in transport and communication has played an important role. Increased returns to scale in production and high income elasticities for differentiated products have also had their impact. These and many other factors have favoured international specialisation and trade, both in tangible goods and in services. The forces working for economic interdependence among nations seem irresistible.

Although the nation-state is still in the 1990s the dominant entity, the increasing interdependence between countries has meant the loss of some degree of sovereignty. Some countries have surrendered a good part of their sovereignty willingly, for example the members of the European Community (although even there we see fierce debate over the degree to which sovereignty should be ceded to a central institution). Others, while unwilling to surrender sovereignty, are nevertheless constrained in how they can exercise their autonomy. Even the United States must nowadays take account of the reactions of other countries when formulating its economic policies.

Although governments are generally aware of the losses that would be incurred if they were to isolate themselves completely from the world economy, they are still often tempted to adopt policies that reduce the degree of dependence. Governments in the advanced industrial countries 
are often concerned to limit the impact on their own economies of changes in the rest of the world, whether these be 'shocks', such as the increase in oil prices in 1973, or 'structural changes', such as the threat to domestic industries of imports from newly industrialising countries. Many less developed countries have also tried to establish a policy of self-reliance. They have tried to isolate themselves from international influences by a policy of import-substitution. It may however be argued that those countries, whether developed or developing, that have grown most quickly in the last few decades have been those that have not attempted to isolate themselves from the world economy.

Whether the degree of interdependence will continue to increase or not, and if so on what lines, is a matter for debate. On the one hand we see increasing interdependence between groups of countries, either formally, as in the European Community or the North American Free Trade Area, or informally, as in the 'Pacific Rim' countries. On the other hand, there is evidence of increasing friction over economic matters, as between the United States, the European Community, and Japan. The 'free trade versus fair trade' debate is important here, providing an impetus towards unilateral action. Some observers have suggested that the world economy will move towards a system of economic blocs, within which there will be free trade, but between which there will not. The forces working for a national identity - perhaps a new type of identity, be it from dominating neighbours or a new type of changed social and political system - are also strong in many countries. Whether existing trends toward internationalisation or new forms of nationalism will get the upper hand is impossible to say. This is primarily a political question.

\section{- International economics as a subject}

Even if most people are agreed that international economic relations are of great importance for most countries, it does not necessarily follow that international economics should be studied as a subject independent of other branches of economics.

There are certainly many policy problems and problems within international economics that the use of economic theory can elucidate. At the same time, it is becoming less tenable for economists to discuss the policy options open to a government as though the economy were closed from the rest of the world, so that much of 'domestic economics' is necessarily discussed in an international setting. However, there are more deep-seated reasons why international economics has a long tradition as a subject in its own right.

Many theorems and insights central to economic theory have been developed by economists working within international economics. The 
theory of comparative advantage and the factor-price equalisation theorem are examples. Both belong to the area usually called the pure theory of international trade. The pure theory of trade can be said to be part of price theory, the terms used in a broad sense. But price theory or micro theory per se seldom pursues the subject to such a degree that all the aspects of the theory which are of interest to a trade theorist are revealed in its full implications. Trade theory is a distinct part of modern economic theory with a rich body of theorems.

Analogous conditions hold for the macroeconomic parts of international economic theory. Some of its results, for instance those about income determination in open economies, are quite straightforward applications of the corresponding parts of the theory for closed economies. But other parts, for instance exchange-rate theory, can hardly be obtained except from a study of the specific theory.

When it comes to the policy aspects of the subject, it is quite obvious that the policy problems faced by an open economy are quite different to those faced by the closed economy. While the assumption that an economy is closed may be tenable for some problems (such as whether to impose a tax on a non-traded good that makes up a minor part of national output), in most cases the discussion must recognise the openness of the economy. The nation is however not only a distinct political entity: it also has many important economic characteristics that set it apart from the larger integrated areas that make up the world economy: the mobility of the factors of production is much larger within the nation than among nations, there are tariffs and taxes on imported goods, different currencies give rise to specific problems, etc. All these lead to international economic policy problems that must be considered in the context of many countries rather than one country.

There are, therefore, from both theoretical and policy points of view, good reasons why international economics is dealt with as a specific branch of economics. Modern economics is a large and diversified subject. A training in general economic theory is the best background for a study of international economics. But it can only be regarded as a background. To obtain a real understanding of the field, the student will have to study international economics directly.

Now we shall now consider briefly five areas in which international economics has had something important to contribute to economics in general, and preview some of the problems and results.

\section{- Comparative advantage and pure theory}

One of the basic questions facing international trade theory is: Why does trade take place? The classical economists saw labour as the only factor of 
production and said that differing labour productivity among countries caused trade. More recent economists have seen the source of trade as being differences in countries' endowments of factors of production. The most recent development has been to explain trade flows in terms of imperfectly competitive markets, so-called intra-industry trade.

A closely linked question is: Why do countries gain by trading? The classical economists said that as long as cost conditions differ between countries, at least one and probably both will gain by trading. The modern theory of intra-industry trade tends to focus as much on the role played by consumers' tastes.

These questions, and their answers, contain the essence of the theory of comparative advantage. The first can be said to state the positive side and the second the normative side. The normative aspect is perhaps the most interesting to the modern student. It demonstrates, on very weak assumptions, that trade will be beneficial to all countries involved in trade. It is important to understand the nature of this theory. It has often been attacked and is often misunderstood. It is still frequently argued that trade is detrimental to countries, today especially in connection with lessdeveloped countries (LDCs). Right from the outset, therefore, we will enter disputed territory. Whatever the student's final opinion is, he will have to undertake a certain amount of theoretical work before he can reach an informed judgement.

One of the central assumptions of the classical economist was that factors of production were fully mobile within countries but not at all mobile between countries. Labour could move freely from New York to Arizona, but it could not cross the border into Mexico. This is an assumption that modern trade theorists have stuck to in elaborating the modern theory of trade. It might seem to be too strong. Within Western Europe, for instance, there have been substantial movements of workers, largely north from Portugal, Spain, southern Italy, Greece and Turkey to France, Germany and Switzerland. But the movements of labour have taken place primarily between somewhat integrated areas. The movement of workers between the United States and Europe, for example, is still insignificant.

For many purposes the assumption that labour is immobile between countries is valid. Using this (and some other fairly stringent assumptions), modern trade theory has proved some startling theorems. One is that trade alone will lead to a complete equalisation of factor prices. Even in the absence of factor movements, if only goods can be traded freely, wages will be equalised.

A study of modern trade theory will also help the student understand one of the basic principles of economics, that of general equilibrium. Trade theory is essentially a branch of general-equilibrium analysis. It is firmly 
embedded in the Walrasian tradition. From there stems the preoccupation with creating a theory that is self-contained, where all variables of importance enter and where all variables are interdependent. Such a theory will of necessity be of an abstract and simplified nature. It works with a few well-defined variables and relies on simplifying assumptions, some of which are of a drastic nature. Its strength lies in the fact that it creates a picture of the world which in important ways is complete.

At the heart of general-equilibrium theory are the notions of determinateness and completeness: the relations which describe an economy must form a complete whole where all the variables of the system can be determined. The viewpoint that all factors which make up an economy hang together and are dependent on one another has had a very strong place in economic theorising. It might even be said to have been the distinctive feature of economics as a science. It had also had important policy implications as it has forced policy-makers to try to view the economy as a whole and not simply try to focus the attention on the effect of a parameter change on one or two obvious variables. The pure theory of trade offers the student an excellent illustration of one of the basic notions of economics as a science.

\section{- Comparative statics: the question of change}

The pure theory of trade is fundamentally a static theory. It studies some aspects of trading economies in the setting of static equilibrium. It abstracts from one fundamental aspect, that of change.

The simplest way to study the effects of change is by the use of comparative statics. We take an economy in a given equilibrium and then introduce a change in some of the basic variables. This is done, for example, in the study of the effects of economic growth on international trade. Growth of production and trade in the world economy has been very rapid in the post-war years. The more precise theory of growth and trade was also primarily developed during this period. From a methodological point of view, this type of theory is also interesting because it illustrates clearly how the static models of pure trade theory can be developed in a comparative-static way. It clearly demonstrates also some of the basic effects of economic growth on the variables in the trade model. One question it answers is the following. Let us assume that economic growth occurs in two trading economies. What will be the effects on the terms of trade (the ratio of export prices to import prices) and on national income? The answer will depend on which sectors growth occurs in and what the income elasticities are.

The effects of increases in factor endowments and technical progress are also studied. These effects can be handled clearly by the use of geometry. 
An understanding of this type of theory therefore does not involve very advanced or difficult methods. The effects of technical progress, for instance, are quite striking. An understanding of this kind of theory is essential also for a broad group of problems outside the field of international trade, so it seems appropriate to treat the theory of economic growth and trade rigorously and explicitly.

\section{Trade policy: is trade good or bad?}

The book is based on the principle of decreasing abstraction. The most theoretical parts are in the beginning, especially in Part I; then, as the exposition develops, it becomes more and more policy oriented - it assumes more of an 'applied' nature. This is because theory is needed to appreciate all the facets of a policy problem. It is logical to start with theory and then proceed to policy, though it perhaps seems that policy problems are sometimes 'easier' to deal with than theoretical questions.

Part 2 is devoted to problems of trade policy. It both demonstrates principles of trade policy, for example the effects of tariffs on trade, and analyses the factual development of trade policy, and in particular the political dimension of the formulation of that policy. One thing Part 2 shows is that free trade, in a world of sovereign states, is usually the best policy except in the case of the few large countries, but that the political pressure to restrict trade may be difficult to resist. However, since some trade is always better than no trade, it is unlikely that trade will ever be eliminated.

The trade problems of the developed countries and the LDCs are seldom of the same kind. One of the trade problems confronting LDCs is the stabilisation of commodity prices. Together with the question of tariff preferences, this problem has dominated the UNCTAD conferences held so far. These questions are also intimately linked with the strivings for a new economic world order.

The proposals for stabilisation of commodity prices are of different kinds. The object of some is to stabilise terms of trade between LDCs and industrial countries; others, less far-reaching, aim at stabilising export prices or export proceeds. To understand the true nature of some of these plans, they must be considered against the models of growth and trade developed earlier. These models show explicitly the basic factors that determine the development of commodity prices in international trade. Therefore, they show clearly which factors have to be controlled if international prices are to be controlled. They give an example of how recent developments in trade theory can be used to elucidate long-standing policy problems. 


\section{Macroeconomic aspects: different currencies}

One of the obvious differences between trade within a country and international trade is that the latter involves different currencies. If a New Yorker trades with a Californian, they both use the same currency, but trade between a New Yorker and a Canadian involves different currencies.

One essential complication in connection with foreign trade is that the relative values of currencies change. One year, $£ 1$ sterling could be worth $\$ 2.00$ US, the next, 1.50. This concerns the balance of payments between countries.

Disequilibria in the external balances of countries give rise to changes in exchange rates. The policy problems surrounding disequilibria in the balance of payments and changes in exchange rates are among the most pertinent ones in the world economy. If anything, they have become more important and attracted increasing attention as domestic capital markets have become increasingly integrated.

The first chapters in Part 3 are devoted to these macroeconomic aspects of international economics. The basic principles of foreign exchange markets are discussed and an explanation is given of how a country's balance of payments can be in disequilibrium and how it can be kept in equilibrium.

International monetary matters have been at the forefront of economic theory in recent years, and important reformulations of theory have taken place. They centre around what is commonly called the monetary approach to the balance of payments. This theory states (to put it somewhat bluntly) that in the long run the exchange rate will primarily be determined by changes in the money supply. An increase in the money supply will cause inflation. This in turn will cause a depreciation of the exchange rate. This is an illustration of 'the law of one price': if the price level increases, the value of the currency will fall proportionately.

\section{The international monetary system and international policy co-ordination}

The international monetary system underwent great changes in the 1970s. Up until 1971 the Bretton Woods system reigned, which meant that exchange rates were fixed. During the 1960s this system was put under greater and greater strain. Finally, it broke down. It has now been replaced by a system of floating exchange rates, but one within which some countries attempt to link their currency to those of other countries. 
A system of floating rates does not, however, solve all balance-ofpayments problems. Exchange-rate changes have been very large, and international capital flows of increasing importance. Some might argue that the problems posed for economies by the current problems may best be solved by the international co-ordination of macroeconomic policies, others that there should be a return to the pegged exchange rate system of Bretton Woods, yet others that international capital movements should once more be regulated. The closing chapters of Part 3 discuss these questions. 